\title{
Water Utility and Management Policy for Effective Sharing of Natural Water Resource in the Costal Dry Zone of Sri Lanka in the North East Region
}

\section{S. S. Sivakumar}

\begin{abstract}
Unlike other natural resources, water is a unique resource, which renews itself. It is due to its constant circulation in the ocean-atmosphere-earth-ocean system. No matter how much water is consumed in daily life, its amount seldom dwindles. With time and under certain conditions water regains its properties and becomes fit for reuse. This is probably the reason why water resources appear to be unlimited for a long time. The North East region of Sri Lanka comprises the whole of eight districts, namely Jaffna, Mannar, Vavuniya, Kilinochchi, Mullaitivu, Trincomalee, Batticaloa, and Ampara and covers an area of $18,881 \mathrm{sq} . \mathrm{km}$. The population is around 3.17 million, with growth rate nearly $1.5 \%$ per annum. Agriculture, including fisheries, has been the principal economic activity in the province. Over $50 \%$ of the total work force, in the region depends on irrigated agriculture for their livelihood. To accelerate the development and effective utilization of water resource identified within the region, a clearly defined policy formulation is essential. Only with a proper policy for the effective utilization and management of water resource, the expected result can be achieved
\end{abstract}

Keywords: Growth Rate, livelihood, Economic Activity, Water Resource

\section{General}

The key consumer of fresh water is agriculture rather than industry. Irrigation of fields, orchards and estates claim almost $80 \%$ of the water consumed the world over (Rao, 1979).

Unfortunately, $97.5 \%$ of all water resources on earth are salty. Consequently, fresh water including the one in glaciers accounts for only $2.5 \%$ Even here the most accessible one is as little as $0.3 \%$. Moreover the natural distribution is extremely uneven (Nandasena, 1999). This unevenness is aggravated by the still greater unevenness of the geographical distribution of human settlements. Shortage is noticed where there is an excess of population and industry. Besides, modern industry, with its manufactures of increasingly complex and diverse products requires not just fresh, but exceptionally clean water. Many countries are short of this clean water. Treatment of fresh water for getting clean water further reduces the bulk of fresh water.

\section{Objective of the Policy}

Objective of the policy is to improve the standard of living of the people in North East region of Sri Lanka by implementing the proposed water utility and management policy of North East region.

\section{Introduction of the Problem}

Due to the long negligence of the proper management of existing water resources, people in this area suffer a lot during dry season even for drinking water. This negligence of the proper management also allowed the sea water to intrude in to the main land through non-perennial river mouths in high tidal time. Apart from the tidal salt-water intrusion, in some places excess pumping of water for irrigation, improper drainage and adhoc land reclamation leads to salination of coastal belts of this reign.

This salination problem together with the conflict situation that prevailed in the North

Eng. (Dr.) S. S. Sivakumar PhD, MSc, BSc, FIE(Sri Lanka), C.Eng. MIE BMPSI, LMICOLD, IMIWRS, LMSLAAS. 
East made a considerable part of 384,657 ha. of good fertile land closer to costal area be abandoned from cultivation and habitation (Sivakumar, 2002). Abandoning quite a lot of coastal land led to salty weeds spreading to bare land and further block the rain water from flowing out to sea leading to water logging and land further interior also to become brackish groundwater. It's high time to stop the fresh groundwater and brackish groundwater interface getting pushed inside to the main land.

Around $375 \mathrm{~km}$ coastal length extending inwards from $1 \mathrm{~km}$ to $8 \mathrm{~km}$ experienced this salination problem. Nearly 45,000 families dependent on fishing, live in this area and are suffering from non availability of fresh water for drinking. More than 75,000 families having 150,000 ha of good fertile cultivation land along the coastal river mouth are having difficulties for their livelihood (Sivakumar, 2002).

The problems causing concern in this vast northern coastal belt is due to highly cavernous and permeable nature of lime stone in this region through which saline water intrudes in land. The groundwater being the main source of irrigation besides the scares rainfall in the area, the affect of saline water intrusion is ruinous. Except a few minor tanks and ponds and some small sand bars, the non perennial rivers are the only surface irrigation facility available. Hence as an alternative source of meeting agriculture water demand, water is being obtained from groundwater in this region.

There are quite a large number of open wells in this coastal region, which have been the main source of supplying fresh ground water to crops as well as the human being. The concentrated local pumping resulted in lowering the water table and this in turn paved the way for easy intrusion of saline water in land due to reversal of hydrological gradient. The result is the deterioration of quality and quantity of ground water. The increase in the total dissolved solids further affects the agricultural outputs and the income of the farmers.

In the last two decades, inadequate rain has resulted in very low recharge to groundwater system. The situation further aggravated when farmers started utilizing water from the wells for irrigation, which was adversely affected due to higher withdrawals, which was the only mode of irrigation available. Continuous use of such water with high percentage of total dissolved salt caused certain deterioration in quality of agricultural sales and persistent withdrawals from these wells caused persistent ingress of saline water in the coastal belt and then created the problem of inadequate drinking water supply in this area during dry season.

\section{Present Status of the Water Resource}

With the increase in population, industrialization and urbanization, demand for water has increased. Population has increased from 1.9 million in 1971 to 2.9 million in 2002 and 3.17 million, which shows a growth, rate of nearly $1.5 \%$ per annum. The domestic and industrial water use has to be given due consideration than the agricultural use. The industrial sector's share of the Gross Domestic Product was $23 \%$ in 1996, compared to about $19 \%$ for agriculture, forestry and fisheries in whole country (Sivakumar, 2002). Preliminary calculations based on per capita water use for domestic needs, water requirement for the irrigation sector and projections for industrial and commercial water needs show a trend of increasing water demand.

Even though the Government has been developing water resources (surface irrigation facilities as well as groundwater extraction facilities) for the economic and social wellbeing of the community, it has found that the scope for further development is reducing gradually. Water resource augmentation is a limited option since new projects tend to be less technically feasible and less economically viable. Therefore the importance of conservation and efficient management of available water resources should be addressed properly.

Groundwater is used in the domestic, agriculture, commercial and industrial sectors. Several government organizations, nongovernmental organizations, commercial enterprises and private sectors are promoting the extraction of ground water without any control or restrictions. This problem of unregulated groundwater use has led to overexploitation of shallow aquifers and water quality problems.

The major demand management consideration with respect to groundwater is that groundwater use is unregulated and 
controlled only by natural occurrence, recharge and the degree of impact by other groundwater uses. This is clearly an area requiring basic water resource management as well as demand management.

At present Central Irrigation Department and provincial Irrigation Department and looking after operation and maintenance of major and medium irrigation schemes and Department of Agrarian Development is looking after operation and maintenance of minor irrigation schemes where as Water Supply and Drainage Board is looking after domestic water supply schemes.

Even though almost all the river basins are tapped by constructing Irrigation schemes, due to poor maintenance by Central Irrigation Department, provincial Irrigation Department and Department of Agrarian Development (due to lack of funds and situation prevailed in the region) duty of the irrigation systems are as high as $10 \mathrm{ft}$ and above. This issue is not adequately addressed by the relevant authorities due to constrains they faced in this region.

Water Supply and Drainage Board is mainly depending on groundwater for its domestic water supply schemes. In most of the places their yield is reducing due to poor recharge. Nowadays they are also trying to get water from surface irrigation schemes for water supply projects.

\section{Policy Implementation Area}

In view of the above facts the areas to be developed to be identified. In the west coast of this region starts from Motharagama, Mannar, Valipadu, Kumilamunai, Nachchikudah to Elephant pass and in the east coast Chundikulam, Mathalan, Salai, Nayaru, Kokulai, Trincomalee, Muthure, Batticaloa, Kalmunai, Pottuvil, and Panama areas. The above area covers the following fifty six river basin mouths (Arumugam, 1956).

1. Kunchikumban aru

2. Palakkattai aru

3. Yan Oya

4. Mee Oya

5. Ma Oya

6. Churian Aru

7. Chavar Aru

8 Palladi aru

9. Nay aru
10.Kodalikallu aru

11. Per aru

12. Maruthapilly Aru

13. Thoravil aru

14. Piramenthal aru

15. Nethali aru

16. Kanakarayan aru

17. Kalawalappu Aru

18. Akkarayan aru

19. Mandekal aru

20. Pallaryan Kaddu

21. Pali aru

22. Chappi aru

23. Parangi Aru

24. Pnkulam aru

25. Panna Oya

26. Palampotta aru

27. Kantalai Aru

28. Mahaweli Ganga

29. Makarachchi Aru

30. Mandan Aru

31. Bodigolla Aru

32. Kirimechchi Aru

33. Pulliyanpota Aru

34. Maduru Oya

35. Miyangolla Ela

36. Mundeni Aru

37. Unnichchi

38. Vett Aru

39. Pathantoppu Aru

40. Mandipattu Aru

41. Mamakada Aru

42. Tumpan Keni

43. Andella Oya

44. Gal Oya

45. Ampalam Oya

46. Pannel Oya

47. Rufus Kulam

48. Kangikadichi Aru

49. Tandiadi Aru

50. Semana Aru

51. Karanda Oya

52. Heda Oya

53. Wila Oya

54. Wila Oya

55. Helawa Aru

56. Girikula Oya

Out of these 56 river basin covering around 19,000 sqr.km only a very few are perennial rivers all others carry water only during rainy season. From an average of 4 million hectormeter of water annually received from rain fall $50 \%$ is lost through evapotranspiration, $20 \%$ seeps down to replenish ground water. Only $30 \%$ or 1.2 Million Hectors is available as stream flow for irrigation and other purposes. 
To accelerate the development and effective utilization of water resources identified within the region a policy change is essential. Only with a proper policy for the effective utilization and management the expected result can be achieved.

\section{Polices Proposed}

The following three main areas of water resources are to be brought under strict policy framework to get maximum utilization of the water resource in effective economic manner.

- Management Polices

- Salinity control Polices

- Recharge Polices

\subsection{Management Polices}

$>$ Improving water management and introducing micro irrigation system

$>$ Change in cropping pattern (crop diversification)

$>$ Regulation of ground water extraction by groundwater legislation

> Compulsory reservation of $20 \%$ to $30 \%$ water in major irrigation schemes for domestic and industrial water use

$>$ Integrated approach of water sharing

$>$ Pricing for water and involvement of private sector

Each policy is explained in detail below

6.1.1 Improving Water Management and Introducing Micro Irrigation System

As almost all the river basins are tapped by constructing irrigation schemes now economically no new irrigation schemes can be constructed. Construction of new irrigation schemes will affect the yield of existing irrigation schemes. Hence after full scale rehabilitation, strict water management policy to be implemented to save water for other water uses such as domestic and industrial water need. Even micro irrigation techniques like drip and sprinkler irrigation techniques to be introduced.

\subsubsection{Change in Cropping Pattern}

After detail study of the soil, climatological and agronomic conditions, prevailing cropping patterns to be changed. The new crops proposed should have low water requirement, salt tolerant, semi salt tolerant crops and boron resistant crops. For the effective implementation of this change in cropping patterns Dept. of Agriculture to be guided by research divisions of Universities.

\subsubsection{Regulation of Groundwater Extraction}

As reported earlier, the uncontrolled development of groundwater by concentration in local pumping without provision for recharging has resulted in over withdrawal causing sea water intrusion in to the land. This needs to be curbed. Therefore some legislative arrangement has to be made to enforce groundwater law, for the prevention of future expansion of construction of wells, limiting pumping engine capacity, electrification of pumps etc.

6.1.4 Compulsory Reservation of $20 \%$ to $30 \%$ Water in any Irrigation Scheme for Domestic and Industrial use as well as Recharge of Groundwater

Considering the acute water shortage during the dry season normally prevailing in the Northern and Eastern Province, a clear decision to be taken to reserve $20 \%$ to $30 \%$ assured water in any irrigation scheme for domestic and industrial use (Sivakumar, 2008). The reservation of water can be used for domestic water use after treatment. Keeping this storage in the tank will recharge in the ground water system also.

\subsubsection{Integrated Approach of Water Sharing}

At present several institutions are involved in utilizing and managing the water resource of their own way. There should be an integrated approach in sharing the water resource among the stake holders. This can be achieved by forming an authority to deal with water resource.

\subsubsection{Pricing for Water}

Every water user should be asked to pay a marginal payment. Then only they will use water in an economical manner. Even involvement of private sector also should be encouraged in improving water resource.

\section{2 Salinity Control Polices}

> Reconstruction of salt water exclusion bunds

$>$ Construction of groundwater dams

$>$ Construction of tidal regulators. 


\subsubsection{Salt Water Exclusion Bunds and Tidal Regulators}

To prevent salty water entering the main land a small bund is to be constructed along the periphery of coastal area adjoining the river mouths \& low MSL areas and the river mouths to be regulated by tidal regulators. The tidal regulator will prevent salt water getting in to the river and will impound fresh or slightly polluted water on the upstream side. During low tidal time if the regulator gates are opened the impounded water will flush out. If this process goes on continuously, there will be flushing out of salt dissolved in coastal area as well as prevention of salt water entry into the river. But this needs good operational arrangement. The tidal regulator gates must be operated properly and designed to resist salty wind corrosion.

\subsubsection{Construction of Groundwater Dams}

An underground dam to prevent groundwater flow to sea could be constructed around one kilometre inside of coastal belt to store rain water which infiltrate into the ground. The site location and spill level to prevent water logging, to be designed after detailed study. The groundwater dams can

- Store the scarce rain water which would otherwise go waste as surface runoff

- Preserve soil moisture in the forest area and support the growth of timber yielding trees.

- Prevent floods in lower reaches

- Enrich ground water potential in the basin

- Raise the ground water table in a relatively poor aquifer to enrich its potential

Hence properly designed, constructed and maintained groundwater dams meet the fresh water needs of human settlement in the basin.

\subsection{Recharge Polices}

$>$ Construction of check dams

$>$ Construction of recharge tanks

$>$ Construction of recharge wells

$>$ Spreading channels

$>$ Reforestation

\subsubsection{Check Dams}

Check dam is a low weir without an outlet, generally constructed across small rivers for storing fresh water for post monsoon flow. In order to allow partial or full floods during monsoon wooden planks or iron gates are to be provided in the bunds of the check dams in suitable areas (not all the places). It provides facility to lift irrigation in surrounding areas. Also permits recharge through percolation in the adjoining wells. These check dams to be constructed in a series of at least $300 \mathrm{~m}$ intervals. The process will increase the ground water potential and push the brackish-fresh water interface towards sea.

\subsubsection{Recharge Water Bodies}

Check dams can be used for diverting surplus water to recharge water bodies (low diversion) in the nearby areas during the periods of floods. In the above centre, recharge water bodies will not only help in increasing the rate of recharge but also improve the quality of ground water.

\subsubsection{Recharge Wells}

Recharge wells are open dug wells $3-4 \mathrm{~m}$ in diameter dug in the bed of rivers or tanks. They are to be filled with rubble and sand filter to some extent to filter the floodwater into the bed, if the material is not a good filter.

\subsubsection{Spreading Canals}

Spreading canals is one of the acceptable measures when recharge is desired along a narrow but a continuous long area. The fresh water barrier that will be formed through induced recharge will also check the movement of saline water from seaside. Therefore, if canals are provided near the coastal line they would work as a good recharge cum salinity control barrier by creating fresh water pool on land side and which will push back sea water intrusion due to its hydrostatic head.

\subsubsection{Reforestation}

The total amount of water entering the ground is governed by the time available for infiltration. If the rain water can be made to move slowly, the amount of infiltration will increase. This type of increase in detention time can be had by physical obstruction of trees and vegetation covers. 
A good tree belt of 15 meters high tree will obstruct wind and effectively protect an area of 450 to 500 meters and have beneficial effects over an area of 1000 to 1500 meters on the leeward side.

The strategy for development of forestry in the region lays emphasis on the reforestation programme to bring at least $30 \%$ of the land area under forest cover and a vigorous social forestry programme with the active participation of the communities in every part of the region. Agro-forestry programme will also be implemented to integrate trees and shrubs on the farms of manure, fuel wood, fodder, medicine etc.

These steps are necessary in order to halt the damage resulting from the indiscriminate destruction of the forests and environmental degradation. The effects are already being felt by less and erratic rainfall, lowering of the underground water table and soil erosion.

\section{Institutional Arrangement for Monitoring Water Quality}

In order to study the extent of salinity ingress area wise and quality wise, special monitoring cell has to be created. This cell should carry out the micro level geophysical and geohydraulic investigations along the coastal area through selected observation wells.

The scope of monthly, well and other monitoring should cover the followings:

- Observations of water level fluctuation through a net work of observation wells during pre monsoon and post monsoon to determine the seasonal variation every year.

- Observation of chemical quality of ground water to monitor seasonal and long term variation.

- Conducting repeat geological sounding on oriented profiles seasonally to determine movement of saline-fresh water interface, if any.

Evaluation and correlation of geoelectrical and geohydrological data will give a comprehensive picture of variation in the areas and sub surface horizon. This type of monitoring and evaluation will help any future project elsewhere. Even Universities can conduct research programs. This also will give an individual technical knowledge basic return from the policy.

\section{Justification of Policy}

All the three proposed policies, if implemented will lead to uplift the living condition of the people of North East region of Sri Lanka. In turn produce healthy human resource for the development of this region by improving the standard of living of the people.

\section{References}

1. Arumugam. S., 1956, River basin Development of Ceylon.

2. Chatuvedi M. C., Water Resource Systems Planning and Management Tata McGraw-Hill Publication New Delhi.

3. Cooray, P. G., 1984. An introduction to the geology of Sri Lanka, Colombo, National Museum of Srilanka, 1984.

4. Administration Report of Department of Agriculture 1999, 2000, 2001, 2002, 2003, North East Province. Trincomalee.

5. Shrma H. D., and Chawla, A. S., 1977, Manual on Groundwater and Tube Well. Technical report 18 Central Board of Irrigation and Power New Delhi- India.

6. Nandasena R. A., 1999, Water for the next decade, SLAAS Proceedings of the 55 th Annual Session of 1999 Part II Presidential addresses etc.

7. Rao S. S., Effectiveness of Percolation tanks as a means of artificial recharge in Drought prone Area in western Maharashtra International Symposium of Hydrological aspects of droughts, December 2-7, 1979, New Delhi.

8. Sivakumar S. S., 2002, Water resource development strategy of north east.

9. Sivakumar S. S., 2008, Conjunctive Use of Surface and Groundwater to Improve Food Productivity in a Restricted Area

10. Thiruvenkeatsamy K. R., Percolation Ponds, 13th AICEME proceedings Association of Engineers India, Calcutta, Pages 14-24 MarchJuly 84 .

11. Yoganarasimhan G. N., and Chand J. P., 1979.

"Integrated Planning of Surface and Groundwater" proceeding of workshop on "Conjunctive use of Surface and Groundwater" at WRDIC University of Roorkee. 